\title{
In vitro decay of Aextoxicon punctatum and Fagus sylvatica woods by white and brown-rot fungi *
}

\author{
V. Pérez, M.T. de Troya, A. T. Martínez, Madrid, Spain, F. J. Gonzălez-Vila,
}

- Sevilla, Spain, E. Arias, Alcalá de Henares, Spain, and A. E. González, Madrid, Spain

Summary. The in vitro decay of Aextoxicon punctatum and Fagus silvatica wood by the fungi Trametes versicolor, Ganoderma australe, Phlebia chrssocrea and Lentinus clathiformis was studied by the agar-block method, and then the decayed woods were analyzed by chemical and spectroscopic techniques. The results demonstrated the strong resistance of the $A$. punctatum wood to the brown-rot fungus L. cyathiformis; the resistance might be related to the low $\mathrm{S} / \mathrm{G}$ lignin ratio in this Austral hardwood. Wood decay by the Austral white-rot fungi $G$. australe and $P$. chrysocrea was rather limited, and preferential degradation of lignin was not produced although all the fungi studied increased wood digestibility. The most characteristic white and brown-rot decay patterns were observed during the in vitro deca! with $T$. versictolor and $L$. cyuthiformis, respectively. Trametes versicolor caused high weight losses and reduced the lignin content of the wood, whereas L. cyathiformis produced a preferential removal of xylan. No important changes in the solid-state ${ }^{13} \mathrm{C}$ NMR spectra were observed after wood degradation by $T$. versicolor, but this technique evidenced an increase in aromatic carbon by L. Cyathiformis. This increase was higher than that found in the Klason lignin content, suggesting the presence of altered lignin fractions in the brown-rotted wood.

\section{Introduction}

Lignin is one of the most complex and least biodegradable of the natural biopolymers, which confers rigidity and resistance to plant tissues. Cellulose and hemicelluloses are the major components of wood and they can be effectively hydrolysed only after eliminating the protection conferred by lignin. The basidiomycetes are the most efficient wood-rotters in nature, and they have developed different decay strategies. The white-rot fungi can degrade lignin and polysaccharides, whereas the brown-rot species modify lignin structure and hydrolyse cellulose with a very limited degradation of lignin (Kirk, Highley 1973). Most white-rot fungi degrade lignin and polysaccha-

* The authors are indebted to Prof. H.D. Lüdemann for the facilities at the Institut für Biophysik und physikalische Biochemie (Regensburg), to A. Navarrete (INIA, Madrid) for her collaboration, and to C. F. Warren (ICE, Alcala de Henares) for her linguistic assistance. The computer program for spectra treatment was developed by G. Almendros (Centro de Ciencias Medioambientales, CSIC, Madrid). This investigation has been funded by the Spanish Biotechnology Program (Grant BIO88-0185) 
rides simultaneously, but some species can produce a preferential degradation of lignin in wood (Blanchette et al. 1985) and other lignocellulosic materials (Valmaseda et al. 1990) and these present considerable interest for biological delignification. This preferential degradation is generally limited to white pockets in wood, but extensive wood delignification by Ganoderma australe and other white-rot fungi has been described in the Chilean rain forest (Zadražil et al. 1982; Martinez et al. 1990a). Lignin degradation by this group of fungi has been intensively investigated and a general scheme of the enzymes and reactions involved has been proposed (Kirk, Farrell 1987; Buswell, Odier 1987; Higuchi 1990) however, little is known on the mechanisms of lignin alteration by the brown-rot species (Highley 1987; Jin et al. 1990; Espejo et al. 1990).

Lignin composition and structure vary in different plant groups (Higuchi 1990). The low biodegradability of softwood lignin is attributed to the predominance of guaiacyl units, but the influence of lignin itself on the biological degradation of different wood types is not well established. The extensive delignification of certain Austral hardwoods has been related to the high syringyl/guaiacyl (S/G) ratio in their lignin (Martinez et al. 1990a).

Solid-state ${ }^{13} \mathrm{C}$ NMR, using the CPMAS ("cross polarization" and "magic angle spinning") technique, is an adequate tool for S/G ratio estimation (Manders 1987), when compared with nitrobenzene or $\mathrm{CuO}$ alkaline degradation which provide values three times higher. When estimating lignin composition in several Austral hardwoods with solid-state ${ }^{13} \mathrm{C}$ NMR, a S/G ratio of 0.75 was found in Aextoxicon punctatum (Aextoxicaceae, Euphorbiales) wood (Martínez et al. 1991 a). This constitutes a very low value when compared with other hardwoods (Manders 1987), and suggests a high degree of lignin condensation and of resistance to degradation.

The aim of the present work has been the study of the fungal degradation of the $A$. punctatum wood by white and brown-rot fungi, as evaluated by weight loss and the chemical and spectroscopic analyses of the decayed wood, and its comparison with the Fagus sylvatica wood.

\section{Material and methods}

\section{Decay tests}

The following fungal strains were obtained from the Centro de Investigaciones Biológicas (IJFM) and INIA Fungal Culture Collections: Trametes versicolor INIA 3A, Phlebiá chrysocrea IJFM A468, Ganoderma australe IJFM A130, and Lentinus cyathiformis (=L. degener) INIA 15A.

The samples of Aextoxicon punctatum ("olivillo") wood were a gift of Dr. H. Peredo (Austral University, Valdivia, Chile). The wood blocks $(50 \times 25 \times 15 \mathrm{~mm})$ of A. punctatum and beech (Fagus sylvatica) were dried at $103^{\circ} \mathrm{C}$, moistened to $12 \%$ water content, sterilized by $\gamma$-radiation, placed on 30 day-old cultures on BMA (benomyl $1.6 \mathrm{mg} / \mathrm{l}$, phenol $5 \mathrm{mg} / \mathrm{l}$, malt extract $30 \mathrm{~g} / \mathrm{l}$, agar $12 \mathrm{~g} / \mathrm{l}$ ) of the four fungi studied, and incubated at $22 \pm 2{ }^{\circ} \mathrm{C}$ and $70 \pm 5 \%$ relative humidity, during 4,8 and 12 months (European Standard 1989). The number of replicates per fungus and wood was three. 
The decayed wood and the controls were dried and milled $(<0.42 \mathrm{~mm})$. The $\mathrm{pH}$ was determined using $0.25 \mathrm{~g}$ of wood suspended in $10 \mathrm{ml}$ of water. The in vitro digestibility was evaluated by treating $0.2 \mathrm{~g}$ of wood with neutral detergent and fungal cellulase (Roughan, Holland 1977).

Wood fractions were estimated by sequential treatments from $1.5 \mathrm{~g}$ of wood. The extractives were removed in a Soxhlet with ethanol-benzene $(1: 2)$ for $8 \mathrm{~h}$, and ethanol for $4 \mathrm{~h}$, and the water-soluble material was extracted with $100 \mathrm{ml}$ at $100^{\circ} \mathrm{C}$ for $3 \mathrm{~h}$. Polysaccharides were then hydrolysed by the Saeman method, and Klason lignin was estimated as the ash-free residue (Effland 1977). The acid-soluble lignin was determined as described in Schöning and Johanson (1975). Neutral sugars in the polysaccharide hydrolysates were analyzed as alditol acetates by gas chromatography (TAPPI 1975).

\section{Spectroscopic analyses}

The infrared spectra were obtained from $2 \mathrm{mg}$ of milled wood and $300 \mathrm{mg}$ of $\mathrm{BrK}$ using a Perkin-Elmer 960. Resolution enhancement was achieved by a derivative method, which included subtraction to the raw spectra of a multiple of its second derivative, and smoothing treatment by the moving average method (Almendros et al. 1992).

Solid-state ${ }^{13} \mathrm{C}$ NMR spectra were obtained with the CPMAS technique at 75.4 MHz in a Bruker MSL 300 spectrometer. The pulse repetition range was $5 \mathrm{~s}$, and the cross polarization contact time was $1 \mathrm{~ms}$. The sweep width was $31.25 \mathrm{kHz}$, the filter width was set to $37.5 \mathrm{kHz}$ and the acquisition time was $0.016 \mathrm{~s}$. Magic-angle spinning was performed at $4 \mathrm{kHz}$ in the commercial Bruker double bearing probes in phase stabilized zirconium dioxide rotors. The chemical shift scale was calibrated with glycine.

\section{Results and discussion}

\section{Analyses of the decayed woods}

The weight loss, in vitro digestibility, and wood fractions analyses of the Aextoxicon punctatum and Fagus sylvatica woods decayed by the brown-rot fungus Lentinus cyathiformis and the white-rot fungi Trametes versicolor, Phlebia chrysocrea and Ganoderma australe, at the three incubation times studied, are presented in Table 1. The two latter fungal species produce extensive delignification of wood in the Chilean rain forest (González et al. 1986; Martínez et al. 1990a) and the Trametes and Lentinus strains were used as reference white and brown-rot fungi for laboratory decay tests (European Standard 1989). In addition to the data presented in the Table 1, the A. punctatum wood showed a very high ash content (over $2 \%$ wood dry weight) compared with the $0.4 \%$ found in the $F$. sylvatica and with the values reported in other hardwoods (Fengel, Wegener 1984). During wood decay by the different fungi a slight 
Table $1 \mathrm{a}$ and $\mathrm{b}$. Characteristics of the Aextoxicon punctatum and Fagus sylvatica woods degraded by fungi (g/100 $\mathrm{g}$ wood dry wt) ${ }^{\mathrm{a}}$

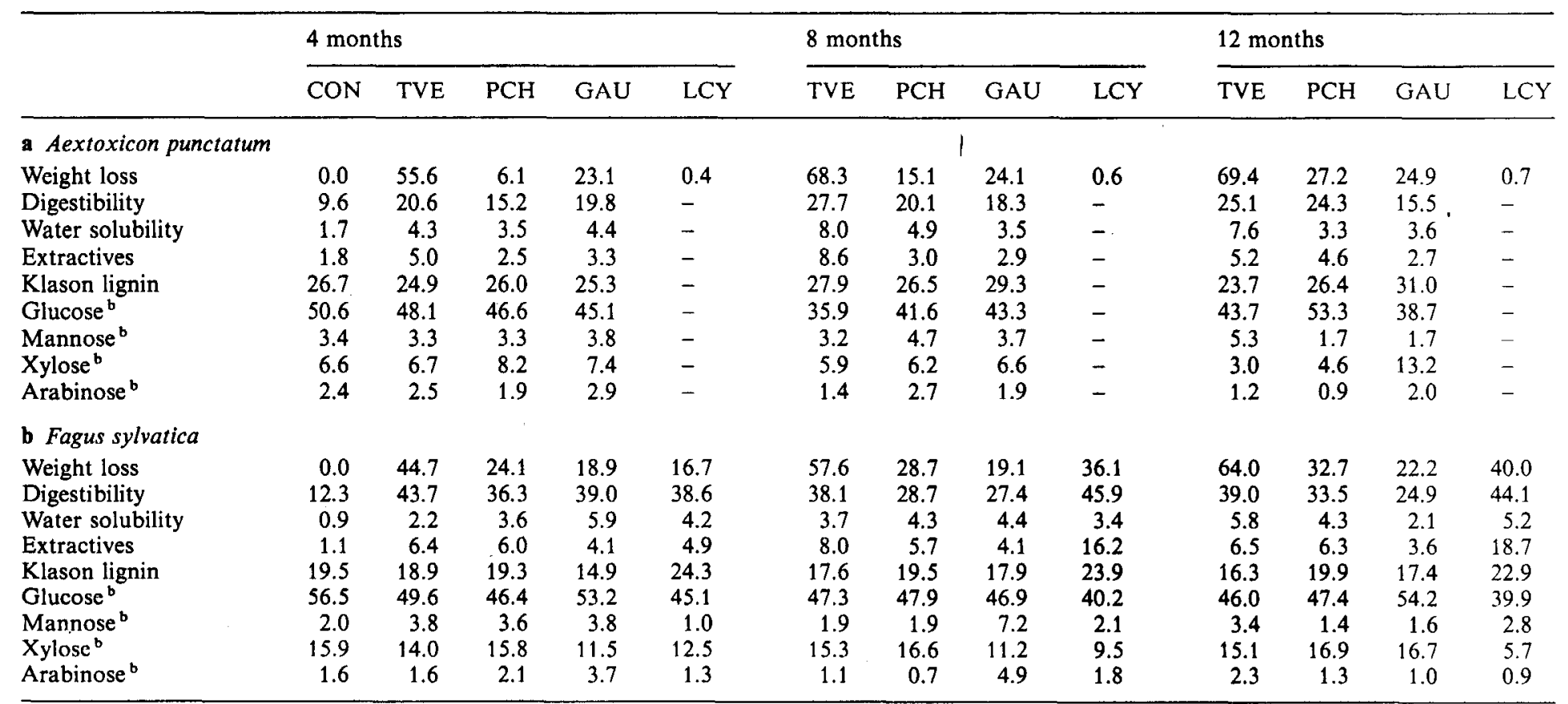

a $\mathrm{CON}=$ sound wood (control), TVE $=$ Trametes versicolor, $\mathrm{PCH}=$ Phlebia chrysocrea, $\mathrm{GAU}=$ Ganoderma australe, $\mathrm{LCY}=$ Lentinus cyathiformis

b Sugars after polysaccharide hydrolysis 
decrease of pH was observed (data not shown), specially in the beech wood, and the acid-soluble lignin varied between $1-3 \%$, with the highest values in the decayed wood.

The highest weight losses in both woods were produced by T. versicolor, as expected from the strong decay capacity of this fungus. Hardwoods are more resistant to brown-rol fungi than softwoods and the limited beech wood decay by $L$. cyathiformis, when compared with $T$. versicolor, shows this tendency. However, the $A$. punctatum wood proved extremely resistant, and no weight loss was produced after 12 months incubation with $L$. cyathiformis.

The two Austral fungi studied produced limited decay in the woods tested. Lignin content did not change during wood decay by $P$. chrysocrea. Ganoderma australe produced the highest decrease in beech lignin after 4 months, but the relative content increased later. After 12 months the values were still lower than the control in the F. sylvatica wood, but they attained $31 \%$ in the $A$. punctatum. The beech wood decay in the agar-block tests was less intense than reported under solid-state fermentation conditions (Bechtold 1989).

Lignin content in both woods was decreased by $T$. versicolor, and this species produced the lowest values after 12 month decay. Simultaneous degradation of xylan and lignin is generally produced during wood decay by white-rot fungi, however this was not observed in the decaying wood blocks. On the other hand, xylan content in the decayed beech wood was progressively lowered by L. cyathiformis. Xylan degradation by brown-rot fungi would facilitate cellulose hydrolysis after eliminating cellulose-lignin bridges through hemicellulose. The increase of wood digestibility by whiterot fungi has been reported previously (Kirk, Moore 1972; Zadražil et al. 1982), however in the present study the highest digestibility values were obtained in beech wood decayed by $L$. cyathiformis. This could be a consequence of increased enzyme accessibility to cellulose, but the high extractive content after brown-rot decay must be also considered. This increase of extractives (nearly 20 fold after 12 months) constitutes a characteristic of the brown-rot decay pattern produced under laboratory and natural conditions (Martínez et al. 1991 b).

\section{IR spectroscopy}

The $1,900-800 \mathrm{~cm}^{-1}$ region of the resolution-enhanced IR spectra of the A.punctatum (Fig. 1) and $F$. sylvatica (Fig. 2) woods degraded by $T$. versicolor, $P$. chrysocrea, $G$. australe and $L$. cyathiformis are presented. The $1,600,1,510$ and $1,425 \mathrm{~cm}^{-1}$ bands are produced by the lignin aromatic ring vibrations, and the band at $1,465 \mathrm{~cm}^{-1}\left(\mathrm{CH}_{3}\right.$ deformation and $\mathrm{CH}_{2}$ bending) is assigned to lignin and polysaccharides. The relatively high intensity of the two former bands in the $A$. punctatum wood accorded with its high lignin content $(26.7 \%)$. The $1,330 \mathrm{~cm}^{-1}$ band can, in part, be attributed to the syringyl groups, and the shoulder observed at $1,270 \mathrm{~cm}^{-1}$ corresponds to the guaiacyl units. The $1,745 / 1,510(\mathrm{C}=\mathrm{O} /$ lignin $)$ ratio was higher in the $F$. sylvatica than in the A.punctatum samples, due to the higher hemicellulose (including $\mathrm{O}$-acetyl-xylan) content of the former wood.

Slight changes in the IR spectra were produced by $G$. australe and $P$. chrysocrea although a relative decrease of the $1,465 \mathrm{~cm}^{-1}$ lignin band was observed. By the other 


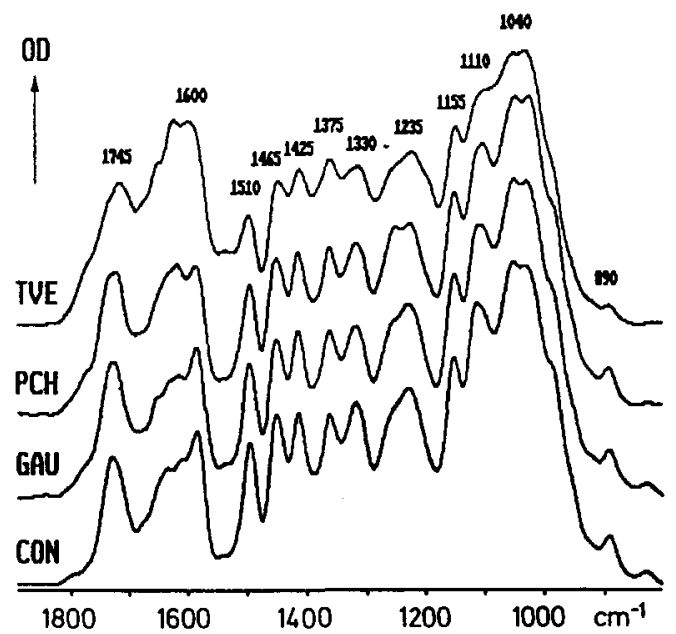

Fig. 1. Infrared spectra of the Aextoxicon punctatum wood degraded by fungi (for abbreviations see Table 1)

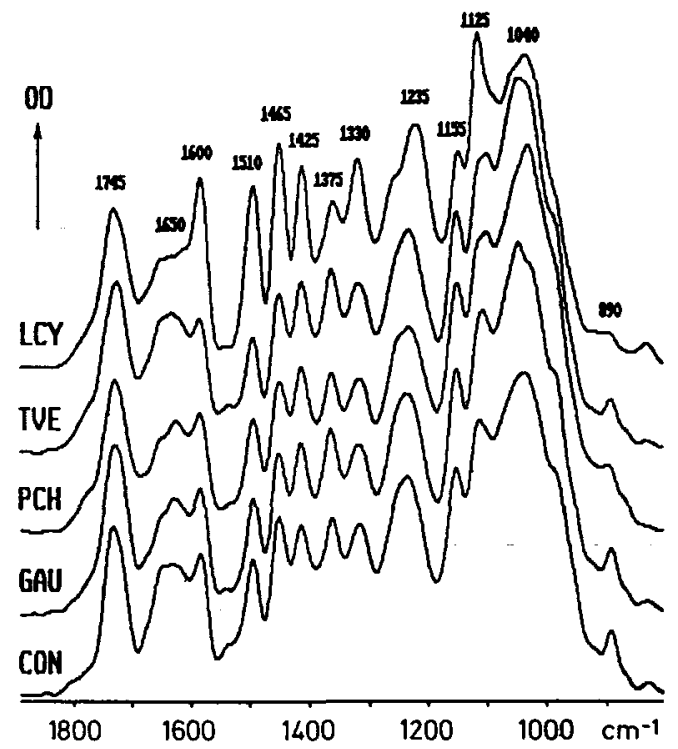

Fig. 2. Infrared spectra of the Fagus sylvatica wood degraded by fungi (for abbreviations see Table 1)

hand, the spectra of the woods decayed by $T$. versicolor and $L$. cyathiformis evidenced the white and brown-rot degradation patterns, observed during natural wood decay by these fungi. The former species increased the protein content $\left(1,645 \mathrm{~cm}^{-1}\right.$ broad band) and reduced the $1,600,1,510,1,465$ and $1,330 \mathrm{~cm}^{-1}$ bands, particularly on the A. punctatum wood. In contrast, the brown-rot fungus $L$. cyathiformis, that only degraded the $F$. sylvatica, increased in this wood the above mentioned lignin bands and the $1,125 \mathrm{~cm}^{-1}$ band, also assigned to the aromatic ring. 


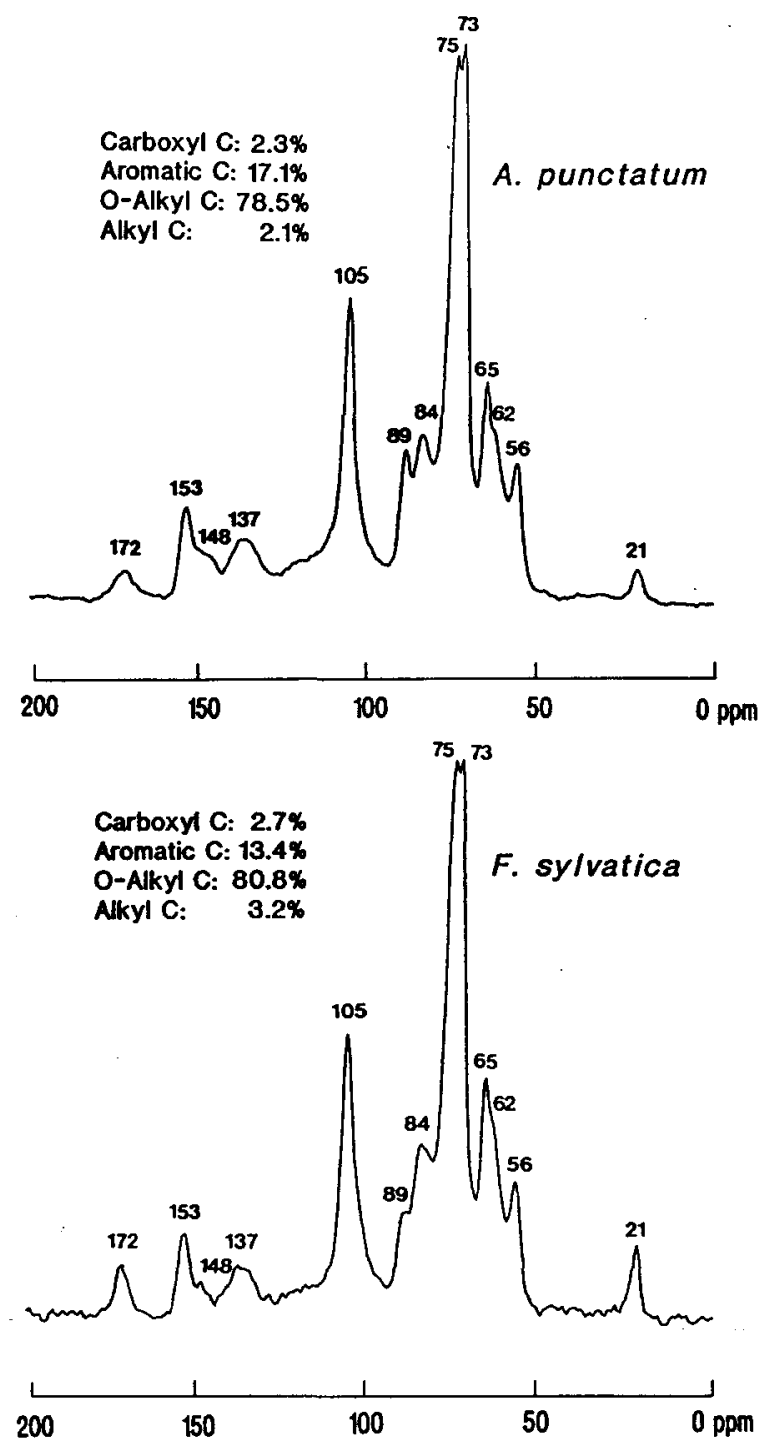

Fig. 3. Solid-state NMR spectra of Aextoxicon punctatum and Fagus sylvatica (the integrations of the spectral areas corresponding to the different $\mathrm{C}$ types are presented as percentages of the total)

\section{Solid-state NMR spectroscopy}

The CPMAS ${ }^{13} \mathrm{C}$ NMR signals in wood spectra (Figs. 3-4) can be assigned to cellulose: $\mathrm{C}_{1}(105 \mathrm{ppm}), \mathrm{C}_{4}(89$ and $84 \mathrm{ppm}), \mathrm{C}_{2}, \mathrm{C}_{3}, \mathrm{C}_{5}(75$ and $73 \mathrm{ppm})$ and $\mathrm{C}_{6}(65$ and $62 \mathrm{ppm})$ and hemicellulose: acetyl $(21 \mathrm{ppm})$ and carbonyl carbons from uronic acids (172 ppm). The main lignin signals correspond to: aromatic $\mathrm{O}$-linked $\mathrm{C}_{3}$ and $\mathrm{C}_{5}$ in $S$ units (153 ppm); aromatic $C_{1}$ and $C_{4}$ in $S$ units (137 ppm); methoxy $C(56 \mathrm{ppm})$; 


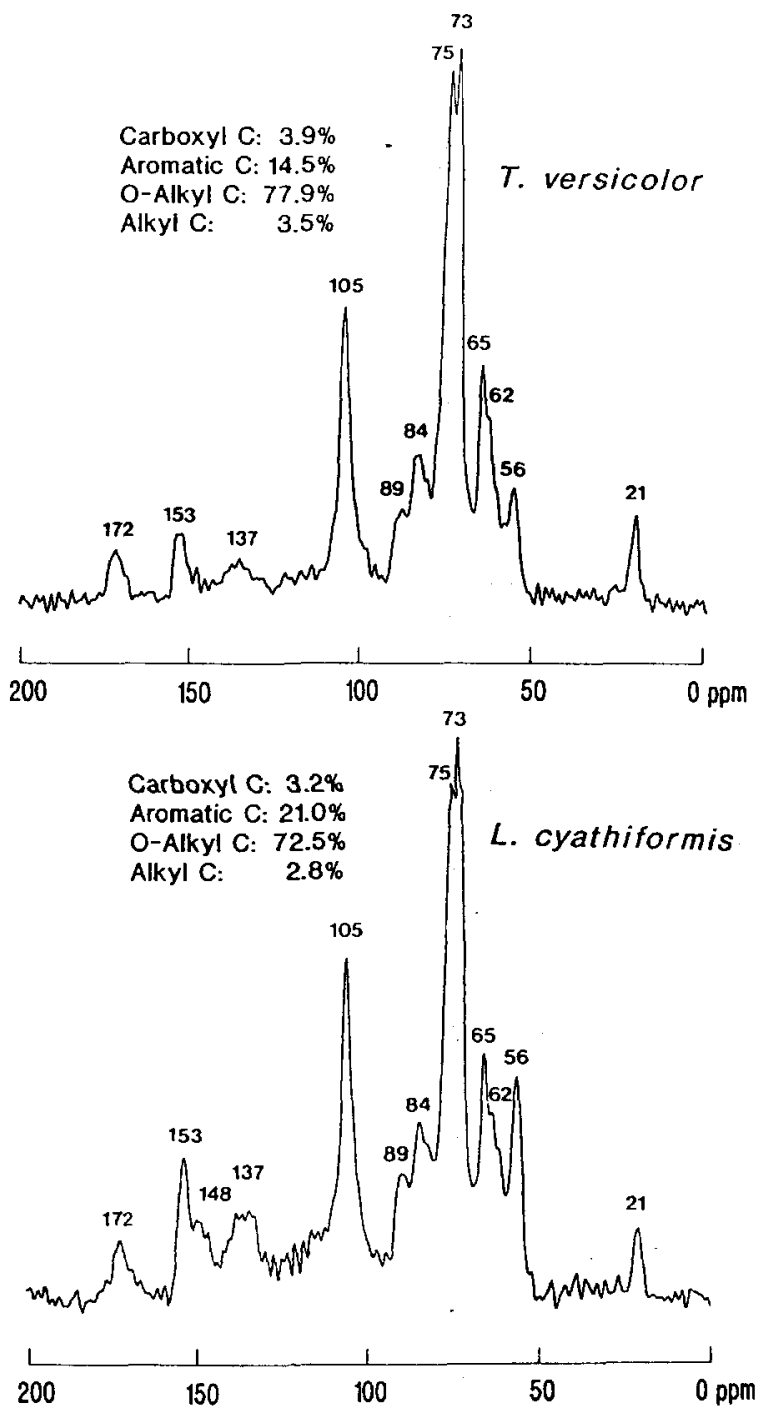

Fig. 4. Solid-state NMR spectra of the Fagus sylvatica wood decayed by Trametes versicolor and Lentinus cyathiformis (the integrations of the spectral areas corresponding to the different $C$ types are presented as percentages of the total)

and the shoulder at $148 \mathrm{ppm}$ corresponds to aromatic $\mathrm{C}$ linked to $\mathrm{O}$ in $\mathrm{G}$ units. The integrations of the areas corresponding to the different carbon types (carboxyl $\mathrm{C}=$ $200-160$ ppm; aromatic $\mathrm{C}=160-110 \mathrm{ppm} ; \mathrm{O}$-alkyl $\mathrm{C}=110-46 \mathrm{ppm}$; alkyl $\mathrm{C}=$ 46-0 ppm) in the CPMAS ${ }^{13} \mathrm{C}$ NMR spectra were calculated and are presented in Figs. 3-4.

Differences between the two woods studied were shown by the solid-state ${ }^{13} \mathrm{C}$ NMR spectra in Fig. 3. The NMR spectrum integration showed lower carboxyl 
$\mathrm{C}$ and higher aromatic $\mathrm{C}$ content in the $A$. punctatum than in the $F$. sylvatica. The latter agrees with the highest lignin content found in the A.punctatum wood.

The production of white and brown-rot decay patterns under in vitro conditions was evidenced by the solid-state ${ }^{13} \mathrm{C}$ NMR spectra of the wood degraded by $T$. versicolor and L. cyathiformis (Fig. 4) and by the chemical analyses presented in Table 1. The simultaneous decay of the beech polysaccharides and lignin by T. versicolor produced few changes in the $\mathrm{O}$-alkyl $\mathrm{C}$ and the aromatic $\mathrm{C}$ contents. However, preferential polysaccharide removal by $L$. cyathiformis caused a decrease in O-alkyl $\mathrm{C}$ (excepting the methoxy signal) and a $56 \%$ increase in the aromatic $\mathrm{C}$ content. This increase was higher than the one obtained with the Klason lignin analysis and probably included lignin-derived products, which could have been removed by the ethanolbenzene extraction before Klason lignin.

No decrease was observed in the $56 \mathrm{ppm}$ methoxy signal after wood decay by L. cyathiformis and the methoxy/aromatic ratio before and after decay was 0.27 . Although lignin demethylation by brown-rot fungi is generally accepted as in the papers of Kirk and Adler (1970) and Kirk (1975), the results obtained here and those from natural brown-rot decay reported by Martinez et al. (1990 b, $1991 \mathrm{~b})$, have not shown evidence of decrease of the methoxy content.

Moderate increases of the carboxyl $\mathrm{C}$ content were found after fungal decay, mainly in the case of $T$. versicolor. The oxidative alteration of lignin side-chains, which increases carboxylic acid yield after lignin depolymerization, has been reported during wood decay by white-rot fungi (Hedges et al. 1988; Martínez et al. 1990a).

\section{Wood decay patterns}

Multivariate data treatment by principal component analysis of the chemical characteristics (shown in Table 1) of the wood samples decayed by the four fungi studied was performed using the Orlóci and Kenkel (1985) programs (Fig. 5). The three replicates in the decay tests were processed separately and presented as triangles, showing the variability inherent to these laboratory tests. The variables with the highest loading factors on the two first axes (explaining $61 \%$ of the total variance) are also presented. The degradation tendency could be represented by the second axis, whereas the two woods studied were differentiated on the first axis. In general, the influence of wood characteristics on the ordination of samples was more important than the effect of the decay patterns produced by the fungi. However, and in spite of the variability among replicates, differences in the decay patterns produced by the fungi could be observed, mainly in the $A$. punctatum. In this wood, $T$. versicolor produced a very distinctive degradation pattern, and the samples corresponding to 8 and 12 months (C, D) occupied an extreme position on the second axis. A similar decay tendency was found in the beech wood decayed by this fungus $(M, N)$, although the differences were less important. In general, $G$. australe and $P$. chrysocrea did not produce a distinct decay pattern, and the corresponding samples were included in the central cluster obtained for each of the woods. However, the beech samples after 12-month decay by $G$. australe $(\mathrm{T})$ were closer to the control $(\mathrm{K})$ than the 4 and 8-month samples $(\mathrm{R}, \mathrm{S})$, showing an indiscriminate degradation of wood components by this fungus at the end of the decay period. The brown-rot pattern could be observed only in the F. sylvatica 


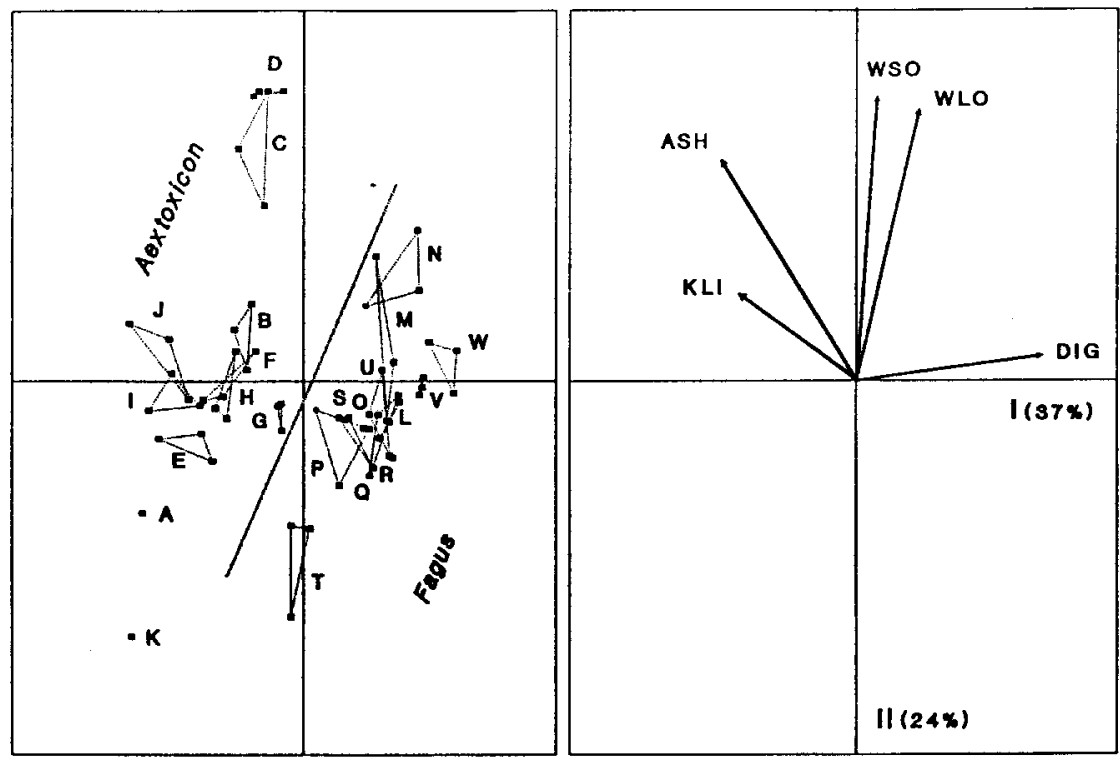

Fig. 5. Principal component analysis of the Aextoxicon punctatum and Fagus sylvatica woods decayed by fungi, showing the affinities between the replicate samples (left) and the variables with the highest loading factors on the two first axes (right). Samples of $A$. punctatum: $\mathrm{A}=\mathrm{con-}$ trol, $\mathrm{B}-\mathrm{D}=$ Trametes versicolor 4, 8, 12 months, $\mathrm{E}-\mathrm{G}=$ Phlebia chrysocrea 4, 8, 12 months, $\mathrm{H}-\mathrm{J}=$ Ganoderma australe $4,8,12$ months; samples of $F$. sylvatica: $\mathrm{K}=$ control, $\mathrm{L}-\mathrm{N}=$ T. versicolor $4,8,12$ months, $\mathrm{O}-\mathrm{Q}=P$. chrysocrea $4,8,12$ months, $\mathrm{R}-\mathrm{T}=G$. australe $4,8,12$ months, $\mathrm{U}-\mathrm{W}=L$. cyathiformis $4,8,12$ months; Variables: ash $=$ ashes, dig = digestibility, $\mathrm{kli}=$ Klason lignin, sli $=$ soluble lignin, wlo $=$ weight loss, wso $=$ water solubility

wood (V, W), since the $A$. punctatum wood showed complete resistance to attack by $L$. cyathiformis during the whole study period.

The very different susceptibility of the $A$. punctatum wood towards white and brown-rot fungi constitutes a characteristic rarely reported in other woods. When studying the natural durability of several Austral hardwoods in laboratory tests (Juacida, Peek 1982), only A. punctatum wood exhibited this strong resistance to the brown-rot fungi Coniophora puteana and Gloeophyllum trabeum. The same authors showed that the resistance of this wood is not related to the presence of fungistatic compounds in the extractive or water soluble fractions. Two noticeable characteristics of $A$. punctatum wood, which might influence fungal decay, are its very low xylan and relatively high lignin contents. The existence of a relationship between the high S/G ratio and the strong biodegradability of lignin in some hardwoods has been suggested (Agosin et al. 1990). Consequently, the low S/G lignin ratio reported by Martínez et al. (1991) after CuO alkaline degradation and solid-state NMR of the A.punctatum wood, could explain the low degradation of this wood in the agar-block tests. Anyway, although the $\mathrm{C}_{5}-\mathrm{C}_{5}$, linkages between $\mathrm{G}$-units are more resistant to chemical breakdown than the ether bonds, the ligninases produced by the white-rot fungi can degrade lignin models with both types of linkages (Kirk, Farrell, 1987; Higuchi 1990). The existence of a unique degrading system responsible for cellulose cleavage and 
lignin modification by the brown-rot fungi has been suggested by Enoki et al. (1988, 1989). However, the mechanism for lignin alteration is still little known and it seems difficult to establish the effect of lignin composition on wood degradability by these fungi.

\section{Conclusions}

The $A$. punctatum wood showed a very high resistance toward the brown-rot fungus L. cyathiformis. The natural durability of this wood might be related to its high lignin content and lignin composition.

White and brown-rot patterns were observed during the in vitro decay of beech wood with $T$. versicolor and $L$. cyathiformis, respectively. The latter produced a preferential removal of xylan, whereas $T$. versicolor caused high weight losses and a reduced lignin content.

Preferential degradation of lignin by G. australe, as described during natural decay, was not observed under the in vitro conditions, although all the fungi studied increased wood digestibility.

Minor changes in the solid-state NMR spectra were observed after wood degradation by $T$. versicolor, but this technique evidenced an increase in aromatic carbon by L. cyathiformis. This increase was higher than the Klason lignin one, suggesting the presence of altered lignin fractions after brown-rot attack.

\section{References}

Agosin, E.; Blanchette, R. A.; Silva, H.; Lapierre, C.; Cease, K. R.; Ibach, R. E.; Abad, A. R.; Muga, P. 1990: Characterization of palo podrido, a natural process of delignification in wood. Appl. Environ. Microbiol. 56: 65-74

Almendros, G.; Gonzảlez-Vila, F. J.; Fründ, R.; Martin, F. J.; Lüdemann, H.-D. 1992: Solidstate NMR studies of fire-induced changes in the structure of humic substances. Sci. Tot. Environ. 117/118: 63-74

Bechtold, R. 1989: Chemische Charakterisierung des Abbaus von Buchenholz durch Ganoderma applanatum im Vergleich zu drei weiteren Weißfäulepilzen. Thesis, University of Karlsruhe

Blanchette, R. A.; Otjen, L.; Effland, M. J.; Eslyn, W. E. 1985: Changes in structural and chemical components of wood delignified by fungi. Wood Sci. Technol 19: 35-46

Buswell, J. A.; Odier, E. 1987: Lignin biodegradation. CRC Crit. Rev. Biotechnol. 6: 1-60

Effland, M. J. 1977: Modified procedure to determine acid-insoluble lignin in wood and pulp. Tappi 60: 143-144

Enoki, A.; Tanaka, H.; Fuse, G. 1988: Degradation of lignin-related compounds, pure cellulose, and wood components by white-rot and brown-rot fungi. Holzforschung 42: 85-93

Enoki, A.; Tanaka, H.; Fuse, G. 1989: Relationship between degradation of wood and production of $\mathrm{H}_{2} \mathrm{O}_{2}$-producing or one electron oxidases by brown-rot fungi. Wood Sci. Technol. 23: $1-12$

Espejo, E.; Agosín, E.; Vicuña, R. 1990: Catabolism of 1,2-diarylethane lignin model compounds by two brown-rot fungi. Arch. Microbiol. 154: 370-374

European Standard 1989: Determination of toxic values of wood preservatives against wooddestroying basidiomycetes cultured on an agar medium. EN-113, Brussels

Fengel, D.; Wegener, G. 1984: Wood. Chemistry, ultrastructure, reactions. Berlin: Walter de Gruyter

González, A. E.; Grinbergs, J.; Griva, E. 1986: Biologische Umwandlung von Holz in Rinderfutter - „Palo podrido“. Zentralbl. Mikrobiol. 141: 181-186 
Hedges, J. I.; Blanchette, R. A.; Weliky, K.; Devol, A. H. 1988: Effects of fungal degradation on the $\mathrm{CuO}$ oxidation products of lignin: A controlled laboratory study. Geochim. Cosmochim. Acta 52: 2717-2726

Highley, T. L. 1987: Biochemical aspects of white-rot and brown-rot decay. Intern. Res. Group Wood Preserv. Doc. No IRG/WP/1319: 1-22

Higuchi, T. 1990: Lignin biochemistry: Biosynthesis and biodegradation. Wood Sci. Technol. 24: $23-63$

Jin, L.; Nicholas, D. D.; Kirk, T. K. 1990: Mineralization of the methoxyl carbon isolated lignin by brown-rot fungi under solid substrate conditions. Wood Sci. Technol. 24: 263-276

Juacida, R.; Peek, R. D. 1982: Die natürliche Dauerhaftigkeit von vier chilenischen Holzarten. Holz Roh-Werkstoff 40: 307-310

Kirk, T. K. 1975: Effects of a brown-rot fungus, Lenzites trabea, on lignin in spruce wood. Holzforschung 29: 99-107

Kirk, T. K.; Adler, E. 1970: Methoxyl-deficient structural elements in lignin of sweetgum decayed by a brown-rot fungus. Acta Chem. Scand. 24: 3379-3390

Kirk, T. K.; Farrell, R. L. 1987: Enzymatic "combustion": The microbial degradation of lignin. Annu. Rev. Microbiol. 41: 465-505

Kirk, T. K.; Highley, T. L. 1973: Quantitative changes in structural components of conifer woods during decay by white- and brown-rot fungi. Phytopathology 63: 1338-1342

Kirk, T. K.; Moore, W. E. 1972: Removing lignin from wood with white-rot fungi and digestibility of resulting wood. Wood Fiber 4: 72-79

Manders, W. F. 1987: Solid-state ${ }^{13} \mathrm{C}-\mathrm{NMR}$ determination of syringyl/guaiacyl ratio in hardwoods. Holzforschung 41: 13-18

Martinez, A. T.; Barrasa, J. M.; Almendros, G.; González, A. E. 1990 a: Fungal transformation of lignocellulosics as revealed by chemical and ultrastructural analyses. In: Coughlan, M. P.; Amaral-Collaço, M. T. (Eds.): Advances in biological treatment of lignocellulosic materials, pp. 129-147. London: Elsevier Appl. Sci.

Martinez, A. T.; González, A. E.; Pérez, V.; González-Vila, F. J.; Fründ, R.; Mulder, M. 1990 b: Study by modern instrumental techniques of wood decayed by white and brown-rot fungi. Abs. $4^{\text {th }}$ Intern. Mycol. Congr., Regensburg, p. 332

Martínez, A. T.; González, A. E.; Prieto, A.; González-Vila, F. J.; Fründ, R. 1991 a: p-Hydroxyphenyl:guaiacyl:syringyl ratio of lignin in some Austral hardwoods estimated by CuOoxidation and solid-state NMR. Holzforschung 45: 279-284

Martínez, A. T.; González, A. E.; Valmaseda, M.; Dale, B. E.; Lambregts, M. J.; Haw, J. F. $1991 \mathrm{~b}$ : Solid-state NMR studies of lignin and plant polysaccharide degradation by fungi. Holzforschung 45 (supplement): $49-54$

Orlóci, L.; Kenkel, N. C. 1985: Introduction to data analysis. Maryland: International Co-operative Publishing House

Roughan, P. G.; Holland, R. 1977: Predicting "in vitro" digestibilities of herbages by exhaustive enzymic hydrolysis of cell wall. J. Sci. Food. Agric. 28: 1057-1064

Schöning, A. G.; Johanson, G. 1965: Absorptiometric determination of acid soluble lignin in semichemical bisulfite pulps and in some woods and plants. Sven. Papperstidn. 68: 616-617

TAPPI 1975: Carbohydrate composition of extractive-free wood and wood pulp by gas-liquid chromatography. Tappi rule T-249 pm-75

Valmaseda, M.; Almendros, G.; Martínez, A. T. 1990: Substrate-dependent degradation patterns in the decay of wheat straw and beech wood by ligninolytic fungi. Appl. Microbiol. Biotechnol. 33: 481-484

Zadražil, F.; Grinbergs, J.; González, A. E. 1982: "Palo podrido"-decomposed wood used as feed. Eur. J. Appl. Microbiol. Biotechnol. 15: 167-171 